\title{
Kecerdasan Matematis Logis Di Era Milenial Terhadap Hasil Belajar Fisika
}

\author{
${ }^{1}$ Sulami Sibua,${ }^{2}$ Dewi Mufidatul Ummah, ${ }^{3}$ Astuti Salim \\ ${ }^{1}$ Departement of Indonesian Language Education, Universitas Khairun, Jl. Bandara Babullah \\ Ternate, 97735, Indonesia. \\ ${ }^{2}$ Departement of Ministry of Early Childhood Education, Universitas Khairun, Jl. Bandara \\ Babullah, 97735, Indonesia. \\ ${ }^{3}$ Department of Physics Education, Universitas Khairun, Jl. Banadara Babullah, 97735, \\ Indonesia. \\ Email Korespondensi: sulamisibua71@gmail.com
}

\begin{tabular}{|c|c|}
\hline Arti & ct \\
\hline $\begin{array}{l}\text { Article History } \\
\text { Received: } 30 \text { Nov } 2021 \\
\text { Revised: } 23 \text { Dec } 2021 \\
\text { Published: } 30 \text { Dec } 2021\end{array}$ & \multirow{2}{*}{$\begin{array}{l}\text { This study aims to determine the effect of logical mathematical intelligence on } \\
\text { physics learning outcomes for class X students at SMAN } 5 \text { Ternate City. The } \\
\text { method used is a quantitative method and is included in the type of case study } \\
\text { research. The research subjects were students of class X SMAN } 5 \text { Ternate City } \\
\text { who were selected randomly. Data analysis using tests and non-tests with } 10 \\
\text { questions for physics learning achievement test instruments and IST } \\
\text { intelligence test instruments for Computing Series (ZR) and Numerical (RA) } \\
\text { Sub-Tests on the IST Test developed by LP3UI (Institute for the Study and } \\
\text { Development of Applied Psychology at the University Indonesia), each of } \\
\text { which consists of } 20 \text { statement items. The data analysis technique in this study } \\
\text { used the SPSS } 16.0 \text { application, namely by testing the prerequisites and } \\
\text { hypotheses. The results of his research show that the correlation coefficient } \\
\text { (rxy) between logical mathematical intelligence and physics learning } \\
\text { achievement is } 0.439 \text { and a significance of O.OOO }<0.5 \text {. Thus, Ho is accepted so } \\
\text { that it can be concluded that "There is a positive relationship between } \\
\text { intrapersonal intelligence and physics learning achievement for students } \\
\text { SMAN } 5 \text { Ternate City" }\end{array}$} \\
\hline $\begin{array}{l}\boldsymbol{K} \boldsymbol{e} \\
\text { log } \\
\text { int } \\
\text { ou } \\
\text { ge }\end{array}$ & \\
\hline Informasi Artikel & Abstrak \\
\hline $\begin{array}{l}\text { Sejarah Artikel } \\
\text { Diterima: } 30 \text { Nov } 2021 \\
\text { Direvisi: } 23 \text { Des } 2021 \\
\text { Dipublikasi: } 30 \text { Des } 2021\end{array}$ & \multirow{2}{*}{$\begin{array}{l}\text { Penelitian ini bertujuan untuk mengetahui pengaruh kecerdasan matematis } \\
\text { logis terhadap hasil belajar fisika siswa kelas X di SMAN } 5 \text { Kota Ternate. } \\
\text { Metode yang digunakan adalah metode kuantitatif dan termasuk dalam jenis } \\
\text { penelitian studi kasus. Subjek penelitian merupakan siswa kelas X SMAN } 5 \\
\text { Kota Ternate yang dipilih secara random. Analisis data dengan menggunakan } \\
\text { tes dan non tes dengan instrumen tes prestasi belajar fisika sebanyak } 10 \text { soal } \\
\text { dan instrument tes kecerdasan IST Soal Sub Tes Deret Hitung (ZR) dan } \\
\text { Numerical (RA) pada Tes IST yang dikembangkan oleh LP3UI (Lembaga } \\
\text { Pengkajian dan Pengembangan Psikologi Terapan Universitas Indonesia).yang } \\
\text { nasing masing terdiri dari } 20 \text { item pernyataan. Teknik analisis data pada } \\
\text { penelitian ini menggunakan aplikasi SPSS 16.0, yaitu dengan menguji } \\
\text { prasyarat dan hipotesis. Hasil penelitannya menunjukkan bahwa koefisien } \\
\text { korelasi (rxy) antara kecerdasan matematis logisdengan prestasi belajar Fisika } \\
\text { sebesar 0,439 dan signifikansi 0,000< 0,5.. Dengan demikian, Ho diterima } \\
\text { sehingga dapat disimpulkan bahwa "Terdapat hubungan yang positif antara } \\
\text { kecerdasan intrapersonal dengan prestasi belajar Fisika Siswa SMAN } 5 \text { Kota } \\
\text { Ternate". }\end{array}$} \\
\hline & \\
\hline
\end{tabular}

Sitasi: Sibua, S., Ummah, D.M., Rani, \& Astuti, S. (2021), Kecerdasan Matematis Logis Di Era Milenial Terhadap Hasil Belajar Fisika di SMA Negeri 5 Kota Ternate, Kappa Journal. 5(2), 219-230. 


\section{PENDAHULUAN}

Generasi milenial adalah adalah generasi yang hidup dipergantian millennium dalam rentang waktu 1980 - 2000 atau gen Y. generasi ini sudah melek teknologi digital, dimana tiap informasi mudah diakses lewat internet. Hal ini pula berdampak di dunia pendidikan baik positif maupun negatif, sebab itu pendidikan membutuhkan perhatian yang khusus.

Sekarang tentu saja tantangan pendidikan lebih kompleks terutama dalam membentuk karakter sebagaimana yang diinginkan Ki Hadjar Dewantara dalam mendidik generasi muda. Pembentukan karakter itu penting terutama dalam menghadapi beragam tantangan bangsa Indonesia ke depan untuk senantiasa bersikap optimis dan terus berjuang memajukan harkat dan martabatnya baik sebagai individu maupun sebagai komunitas manusia. Tantangan pendidikan di era milenial sekarang ini, pertama-tama perkembangan teknologi yang pesat pada masa ini memberikan dampak positif dan negatif pada pendidikn di Indonesia. Dampak positif yang dirasakan adalah semakin mudahnya peserta didik mendapatkan informasi tentang materi pembelajaran di sekolah. Siswa memiliki akses yang luas untuk meningkatkan kompetensi paedogogiknya sehingga diharapkan akan meningkatkan kualitas output pendidikan. Namun, di sisi lain era digitalisasi membawa dampak negatif apabila siswa tidak cerdas dalam mensikapinya. Bermunculan berbagai permasalahan pendidikan yang disebabkan informasi dari dunia maya seperti cyber bullying, tawuran antar sekolah, kekerasan seksual, penculikan, penipuan ataupun kriminalitas yang lain. Hal ini menjadi sebuah tantangan agar pendidikan di Indonesia tidak hanya melahirkan generasi yang cerdas secara akademik saja namun, cerdas secara emosional, intrapersonal dan kecerdasan lainnya.

Hal yang lain yang perlu untuk diperhatikan bahwa informasi datang lebih cepat, massif dan meluas sehingga tidak bisa diatasi dengan sekedar pergantian kurikulum. Berapa kali pergantian kurikulum tidak akan pernah mampu mengejar percepatan informasi yang ada. Sehingga bukan materi kurikulum yang diperlukan, melainkan bagaimana pendekatan guru dan murid dalam berinteraksi akan lebih penting terutama dalam hal keteladanan, membangun kehendak, dan menguatkan dengan bekal ilmu pengetahuan tentunya sehingga anak didiknya mampu mengatasi tantangan hidupnya.

Indonesia merupakan negara berkembang dengan memiliki banyak potensi yang dapat diandalkan, mulai dari letak geografis, memiliki sumber daya alam yang melimpah dan memiliki sumber daya manusia manusia yanng besar. Dengan memanfaatkan potensi-potensi yang dimiliki, negara Indonesia dapat bersaing dengan negara lainnya yang sudah lebih maju. Terutama pada sektor sumber daya manusia, dimana pada saat ini Indonesia memiliki kurang lebih 50\% generasi milenial pada usia produktif yang pada tahun 2020 sampai tahun 2030 akan mencapai $70 \%$ usia produktif. Ini akan menjadi momentum kebangkitan negara Indonesia menghadapi era globalisasi yang sudah masuk ke semua sistem kehidupan masyarakat (Lalo: 2018).

Kecerdasan pada mulanya diartikan dalam bahasa sehari-hari sebagai kemampuan untuk menyelesaikan persoalan-persoalan praktis, dan terdapat persepsi bahwa kemampuan untuk belajar berasal dari kapasitas kognitif. Selanjutnya, makna ini harus diperluas dan lebih fundamental karena pada dasarnya kecerdasan dan aspek kognitif tak terpisahkan dari aktifitas pikiran atau kesadaran manusia secara utuh dalam hubungannya dengan aspek-aspek diri manusia seutuhnya serta interaksinya dengan lingkungannya Kecerdasan bagi seseorang memiliki manfaat yang besar bagi diri sendiri dan untuk pergaulannya di masyarakat. Pada 
umumnya tingkat kecerdasan yang dimiliki seseorang akan menentukan penghargaan orang lain terhadap dirinya. Setiap orangtua menginginkan anaknya menjadi cerdas, tetapi untuk mewujudkan anak yang cerdas tidaklah semudah membalikkan telapak tangan. Anak perlu mendapatkan kesempatan agar dapat mengembangkan seluruh aspek kecerdasannya.

Kecerdasan matematis-logis adalah kecerdasan yang melibatkan keterampilan mengolah angka dengan baik dan atau kemahiran menggunakan penalaran atau logika dengan benar. Kecerdasan ini meliputi kepekaan pada hubungan logis, hubungan sebab akibat, dan logika-logika lainnya.

Kecerdasan logis matematis merupakan salah satu dari delapan teori kecerdasan majemuk (Multiple Intellegence) yang diperkenalkan oleh Howard Gardner. Gardner menjelaskan bahwa teori tentang kecerdasan majemuk merupakan salah satu perkembangan yang paling penting dan menjanjikan dalam pendidikan dewasa ini. Teori Kecerdasan Majemuk didasarkan atas karya Howard Gardner, pakar psikologi perkembangan, yang berupaya menciptakan teori baru tentang pengetahuan sebagai bagian dari karyanya di Universitas Harvard. Kecerdasan logis matematis adalah kecakapan untuk menghitung, mengkuantitatif, merumuskan proposisi dan hipotesis, serta memecahkan perhitunganperhitungan matematis yang kompleks.

Tujuan belajar dalam pendidikan formal sudah diatur pada Peraturan Pemerintah nomor 19 Tahun 2005 Tentang Standar Nasional Pendidikan pasal 1 ayat (4), yaitu standar kualifikasi kemampuan lulusan yang mencakup sikap, pengetahuan, dan keterampilan. Sikap, pengetahuan, dan keterampilan yang dimaksud tersebut tentunya adalah yang bersifat positif pada siswa. Standar kompetensi lulusan tersebut yang kemudian digunakan untuk menentukan kelulusan seorang siswa. Salah satu pelajaran yang diberikan kepada siswa adalah fisika. Pelajaran fisika ini merupakan pelajaran yang bersifat penerapan. Hampir semua jenjang mempelajarinya ada yang secara umum maupun khusus. Serta aplikasi di kehidupan sehari - hari yang mudah ditemukan.

Meskipun fisika merupakan pelajaran yang menekankan pada hitungan secara matematis dengan beragam tingkat kesulitan, namun sebagian besar siswa kurang berperan aktif dalam belajar. Anggapan bahwa fisika merupakan matapelajaran yang sulit dan rumus yang membingungkan juga sering didengungkan. Peserta didik tidak hanya mempelajari mengenai konsep hukum atau rumus-rumus tetapi juga belajar bagaimana menggunakan konsep tersebut dalam menyelesaikan masalah fisika yang dapat berupa soal-soal fisika. Dalam prosesnya, peserta didik harus menerjemahkan soal-soal fisika tersebut ke dalam bahasa matematik, baik dengan bantuan gambar, grafik maupun rumus kemudian menyelesaikannya dengan prosedur-prosedur matematika. Matematika dan fisika memiliki hubungan yang erat, yaitu (1) metode matematika digunakan dalam fisika dan (2) konsep, pendapat dan cara berfikir fisika digunakan dalam matematika. Sehingga hubungan antara fisika dan matematika tidak boleh diabaikan dalam disiplin ilmu.

Ilmu fisika menjelaskan segala sesuatunya dengan bahasa matematis, tentu ini menjadi kompleks bagi siswa karena tidak hanya membutuhkan kemampuan kemampuan konsep semata tetapi lebih dari itu. Namun pada kenyataannya adalah tidak semua siswa menyukai bahkan memiliki kecerdasan matematis logis. Oleh karenanya, guru yang baik akan berusaha untuk mengakomodasi kebutuhan setiap siswa sehingga memperoleh hasil belajar yang baik. Salah satu kebutuhan tersebut adalah tersedianya sumber belajar yang 
tepat dan sesuai dengan karakteristik siswa, misalnya dengan fasilitas pembelajaran yang memadai.

Suria sumantri dikutip dalam Salim (2012) berpendapat bahwa bahasa numerik mempunyai kelebihan lain dibandingkan dengan bahasa verbal. Matematika mengembangkan bahasa numerik yang memungkinkan kita untuk melakukan pengukuran secara kuantitatif. Dari pendapat tersebut dapat dijelaskan bahwa dengan bahasa verbal kita tidak dapat mengetahui dengan tepat atau secara pasti mengenai ukuran dari suatu objek dari suatu benda yang akan diukur, akan tetapi dengan matematika melalui bahasa numerik akan dapat diketahui kepastian ukuran dari suatu objek tersebut. Fisika bagian dari Ilmu MIPA yang menggunakan bahasa numerik untuk pembuktian secara matematis, misalnya melalui pengukuran, maka akan dapat diketahui dengan tepat berapa panjang sebatang logam, dan berapa pertambahan panjangnya apabila logam tersebut dipanaskan.

Dari uraian di atas, perolehan nilai fisika yang rendah tentu dapat mencerminkan adanya ragam kesulitan dalam mempelajari materi fisika, Sejalan dengan itu, berbagai kecerdasan dasar pada diri siswa dapat diukur, seiring berkembangnya zaman digital di era milenial ini.

Kecerdasan logis matematis, sangat berperan bagi siswa dalam memahami pelajaran matematika yang bersifat abstrak. Menurut Hans Freudental dalam Marsigit tahun 2008 yang dikutip kembali oleh Mujiani (2016), menyatakan matematika merupakan aktivitas insani (human activities) dan harus dikaitkan dengan realitas.

\section{METODE}

Penelitian ini menggunakan metode survey dengan analisis korelasional. Sehingga desain penelitian adalah sebagai berikut:

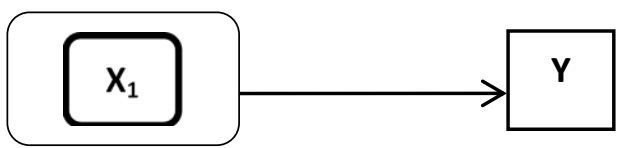

keterangan: $\mathrm{x}$ : kecerdasan matematis logis , $\quad \mathrm{Y}$ : Hasil Belajar siswa

Metode analisis data yang digunakan dalam penelitian ini adalah teknik korelasi product moment dari Pearson (Azwar, 1992), yaitu analisis statistik untuk menguji hipotesis yang berorientasi korelasi dengan tujuan untuk melihat hubungan antara kecerdasan matematis logis (variabel bebas X) terhadap prestasi belajar Fisika (variabael terikat Y).

Setelah data terkumpul, selanjutnya data diolah menggunakan teknik alisis data. Tujuan dari analisis data yaitu untuk membuktikan hipotesis yang diajukan. Analisis data yang digunakan dalam penelitian ini yaitu dengan analisis deskriptif. Analisis deskriptif dimaksudkan agar data yang diamati lebih bermakna dan komunikatif dengan menginterpretasikan data yang terkumpul Saifuddin Azwar (2006: 105) menjelaskan bahwa interpretasi skala psikologi selalu bersifat normatif, artinya makna skor diacukan pada posisi relatif skor dalam suatu kelompok yang telah dibatasi terlebih dahulu. Untuk kategorisasi ordinal, subjek digolongkan menjadi 3 bagian sebagai berikut: 
Tabel 1.Rumus Kategorisasi Variabel

\begin{tabular}{lll}
\hline No & Kategori Interval & \\
\hline 1 & Tinggi & $\mathrm{X}>\mu+1.0 \mathrm{sd}$ \\
\hline 2 & Sedang & $\mu-1,0 \mathrm{sd}<\mathrm{X}<\mu+1,0 \mathrm{sd}$ \\
\hline 3 & Rendah & $\mathrm{X}<\mu-1,0 \mathrm{sd}$ \\
\hline
\end{tabular}

(Saifuddin Azwar, 2006: 109)

Keterangan:

$\mathrm{X}=$ Jumlah skor yang diperoleh siswa

$\mathrm{Sd}=$ Standar deviasi

$\mu=$ mean/ rerata Untuk mengetahui tingkat hubungan atau korelasi antara variabel bebas yaitu kecerdasan intrapersonal serta variabel terikat yaitu prestasi belajar siswa, dilakukan dengan pengujian variabel penelitian dengan menggunakan statistik.

Teknik analisis data statistik yang digunakan dalam pemelitian ini sebagai berikut:

\section{HASIL DAN PEMBAHASAN}

Penelitian ini dilakukan pada kelas X SMA N 5 Kota Ternate tahun ajaran 2019/2020 sebagai subjek dan populasi penelitian. SMA ini berada di Jln. Batu Angus, Dufa Dufa, Kec. Ternate Utara, Kota Ternate Prov. Maluku Utara Adapun populasi dalam penelitian ini berjumlah 162 siswa dan diambil sampel sebanyak 28 siswa.

Sebelum dilakukan analisis untuk mengetahui korelasi antara kecerdasan intrapersonal dengan prestasi belajar, serta kecerdasan matematis dengan prestasi belajar, terlebih dahulu akan disajikan analisis deskriptif dari variabel yang akan diteliti. Analisis deskriptif dilakukan untuk mengetahui frekuensi dari tiap variabel. Data yang digunakan untuk analisis deskriptif berasal dari skala kecerdasan intrapersonal, kecerdasan logis matematis dan nilai Ulangan Tengah Semester kelas X pelajaran Fisika. Berikut analisis deskriptif dari variabel yang diteliti:

a. Kecerdasan Matematis Logis

Pengumpulan data untuk mengungkap kecerdasan matematis logis diperoleh melalui tes dengan jumlah pernyataan sebanyak 20 butir dan diberikan kepada responden yang berjumlah 28 siswa. Setiap butir soal diberikan skor 1, dan jika salah digunakan skor 0 . Berdasarkan kriteria tersebut dapat dilihat bahwa kemungkinan skor tertinggi yaitu 20 dan kemungkinan skor terendah yaitu 0. Setelah data diolah menggunakan SPSS, diperoleh nilai mean sebesar 7,11 nilai median sebesar 6, nilai modus sebesar 6, nilai terendah sebesar 3, nilai tertinggi sebesar 15, dan standar deviasi sebesar 3,49. Data median dan standar deviasi tersebut kemudian diklasifikasikan dalam tabel distribusi frekuensi kecerdasan matematislogis sebagai berikut:

Tabel 2. Tabel Rumus Klasifikasi Matematis Logis

\begin{tabular}{llc}
\hline No & Interval & Kategori Interval \\
\hline 1 & $X>(7,11+1.0 \times 3,49)$ & Tinggi \\
\hline 2 & $(7,11-1,0 \times 3,49)<X<7,11+1,0 \times 3,49)$ & Sedang \\
\hline 3 & $X<(7,11-1,0 \times 3,49)$ & Rendah \\
\hline
\end{tabular}


Berdasarkan tabel rumus klasifikasi di atas, maka data kecerdasan matematis logis dapat dikategorisasikan dalam tabel berikut:

Tabel 3. Tabel Klasifikasi Kecerdasan Matematis Logis

\begin{tabular}{lllcc}
\hline No & Kategori & Interval & Frekuensi & Prosentase \\
\hline 1 & Tinggi & $\mathrm{X}>10,6$ & 6 & $21,42 \%$ \\
\hline 2 & Sedang & $10,6<\mathrm{X}<3,62$ & 18 & $64,28 \%$ \\
\hline 3 & Rendah & $\mathrm{X}<3,62$ & 4 & $14,28 \%$ \\
\hline & & JUMLAH & & $100 \%$ \\
\hline
\end{tabular}

Berdasarkan tabel klasifikasi kecerdasan matematis logis tersebut dapat diartikan bahwa.

1) Tinggi menunjukkan siswa dengan kecerdasan matematis logis tinggi yang memperoleh skor total lebih dari 10,6 dalam soal tesmatematis logis. Dalam tabel tersebut ditunjukkan sebanyak 4 siswa tergolong memiliki kecerdasan matematis logis tinggi dengan presentase $21,42 \%$.

2) Sedang menunjukkan siswa dengan kecerdasan matematis logis sedang yang memperoleh skor total antara 3,62 sampai 10,6 dalam skala kecerdasan intrapersonal. Dalam tabel tersebut ditemukan sebanyak 18 siswa tergolong memiliki kecerdasan matematis logis yang rendah dengan presentase $64,28 \%$.

3) Rendah menunjukkan siswa dengan kecerdasan matematis logis yang rendah dengan perolehan skor kurang dari 3,62 . Dalam tabel tersebut ditunjukkan sebanyak 4 siswa tergolong memiliki kecerdasan matematis logis yang rendah dengan presentase $14,28 \%$.

Dari uraian tersebut dapat disimpulkan bahwa sebagian besar siswa kelas X3 SMAN 5 Kota Ternate memiliki kecerdasan matematis logis dengan kategorisasi sedang. Adapun sebaran dari tiap kategori bisa dilihat dari gambar 1 sebagai berikut:

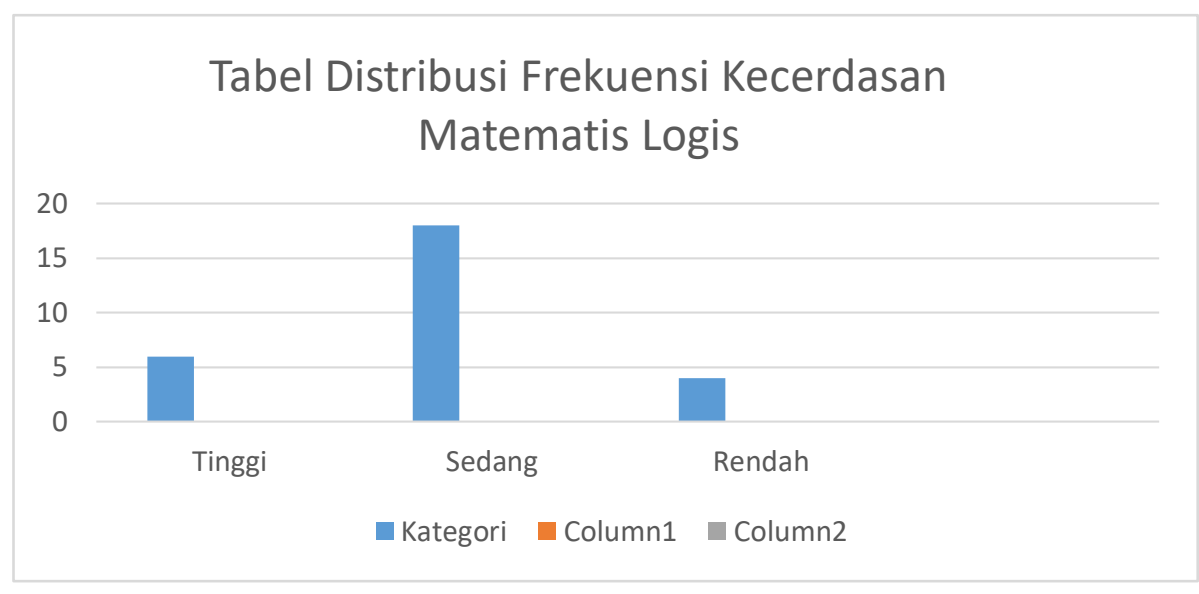

Gambar 1. Tabel distribusi frekuensi kecerdasan matematis logis 


\section{b. Prestasi Belajar}

Prestasi belajar siswa diperoleh dari nilai Ujian Tengah semester kelas X3 SMAN 5 Ternate tahun ajaran 2014/2015 dengan jumlah sampel sebanyak 28 siswa. Setelah dilakukan analisis deskriptif melalui program SPSS diperoleh nilai mean sebesar 54,18 nilai median sebesar 56, nilai modus sebesar 45, standar deviasi sebesar 1,3049, nilai teringgi sebesar 79, dan nilai terendah sebesar 34. Berdasarkan data mean dan standar deviasi yang diperoleh melalui pengolahan data tersebut kemudian diklasifikasikan dalam rumus tabel distribusi frekuensi prestasi sebagai berikut:

Tabel 4. Tabel Rumus Klasifikasi Hasil Belajar Fisika

\begin{tabular}{llc}
\hline No & Interval & Kategori Interval \\
\hline 1 & $\mathrm{X}>(54,18+1.0 \times 13,049)$ & Tinggi \\
\hline 2 & $(54,18-1,0 \times 13,049)<\mathrm{X}<54,18+1,0 \times$ & Sedang \\
& $13,049)$ & \\
\hline 3 & $\mathrm{X}<(54,18-1,0 \times 13,049)$ & Rendah \\
\hline
\end{tabular}

Berdasarkan tabel rumus klasifikasi di atas, maka data kecerdasan intrapersonal dapat dikategorisasikan dalam tabel berikut:

Tabel 5. Tabel Klasifikasi Hasil Belajar Fisika

\begin{tabular}{lllcc}
\hline No & Kategori & Interval & Frekuensi & Prosentase \\
\hline 1 & Tinggi & $\mathrm{X}>67,229$ & 3 & $10,7 \%$ \\
\hline 2 & Sedang & $67,229<\mathrm{X}<41,131$ & 20 & $71,4 \%$ \\
\hline 3 & Rendah & $\mathrm{X}<41,131$ & 5 & $17,9 \%$ \\
\hline & \multicolumn{2}{c}{ JUMLAH } & & $100 \%$ \\
\hline
\end{tabular}

Berdasarkan tabel klasifikasi kecerdasan intrapersonal di atas dapat diperoleh informasi sebagai berikut.

1) Tinggi diartikan sebagai kategori siswa dengan prestasi belajar Fisika tinggi dengan nilai hasil belajar Fisika lebih dari 67,229. Berdasarkan tabel tersebut terdapat 3 siswa yang tergolong memiliki prestasi belajar yang tinggi dengan presentase sebesar 10,7\%.

2) Sedang diartikan sebagai kategori siswa dengan prestasi belajar Fisika tinggi dengan nilai hasil belajar Fisika antara 45,131 sampai 67,229. Berdasarkan tabel di atas terdapat 20 siswa termasuk dalam kategori prestasi belajar yang sedang dengan sebesar presentasi $71,4 \%$.

3) Rendah diiartikan sebagai kategori siswa dengan prestasi belajar yang rendah dengan prestasi belajar Fisika tinggi dengan nilai hasil belajar Fisika kurang dari 45,131. Berdasarkan tabel tersebut ditemukan sebanyak 5 siswa tergolong dalam kategori prestasi belajar yang rendah dengan presentasi sebesar 17,9\%.

Dari uraian tersebut dapat disimpulkan bahwa sebagian besar siswa kelas X3 SMAN 5 Kota Ternate memiliki kemampuan belajar Fisika dengan kategorisasi sedang. Adapun sebaran dari tiap kategori bisa dilihat dari tabel sbb: 


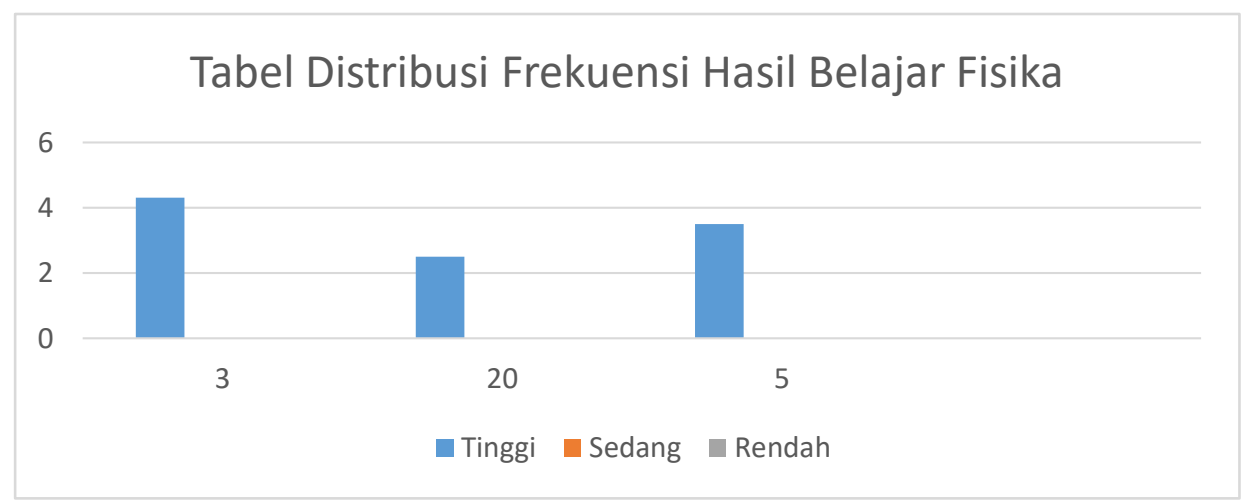

Gambar 2. Tabel distribusi frekuensi hasil belajar fisika

Uji Hipotesis Hubungan antara kecerdasan intrapersonal dengan prestasi belajar Fisika pada penelitian ini dicari dengan menggunakan rumus korelasi Product Moment dengan bantuan program SPSS 16. Untuk mengetahui apakah hipotesis diterima ataupun ditolak, maka dilakukan uji hipotesis dengan taraf kesalahan 5\%. Adapun hipotesis yang diajukan dalam penelitian ini adalah sebagai berikut.

Ho : Tidak terdapat hubungan yang positif dan signifikan antara kecerdasan matematis logis dan prestasi belajar siswa kelas X3 Siswa SMAN 5 Ternate

Ha : Terdapat hubungan yang positif dan signifikan antara kecerdasan matematis logis dan prestasi belajar siswa kelas X3 Siswa SMAN 5 Ternate

Adapun kriteria pengambilan keputusannya yaitu jika rhitung bernilai positif, maka terdapat hubungan positif antara variabel kecerdasan matematis logis dengan variabel prestasi belajar Fisika. Sebaliknya jika rhitung bernilai negatif, maka tidak ada hubungan antara kedua variable $\mathrm{x}$ terhadap variabel $\mathrm{Y}$. Sedangkan untuk menghitung uji signifikansi dilakukan dengan cara membandingkan rhitung dengan rtabel. Apabila rhitung $<\mathrm{r}$ tabel, maka Ho diterima dan Ha ditolak. Tetapi sebaliknya apabila rhitung > rtabel, maka Ha diterima dan Ho ditolak. Dari perhitungan dengan bantuan program SPSS 16 diperoleh hasil sebagai berikut.

Tabel 6. Hasil Korelasi Kecerdasan Matematis Logis dengan prestasi belajar Fisika

\begin{tabular}{|c|c|c|c|}
\hline \multicolumn{4}{|c|}{ Correlations } \\
\hline & & $\begin{array}{c}\text { MATEMATIS_ } \\
\text { LOGIS }\end{array}$ & $\begin{array}{l}\text { HASIL } \\
\text { BELA,JAR_- } \\
\text { FISIKA - }\end{array}$ \\
\hline MATEMATIS_LOGIS & $\begin{array}{l}\text { Pearson Correlation } \\
\text { Sig. (2-tailed) } \\
N\end{array}$ & $\begin{array}{r}1 \\
28\end{array}$ & $\begin{array}{r}.688^{\prime \prime} \\
.000 \\
28\end{array}$ \\
\hline HASIL_BELAJAR_FISIKA & $\begin{array}{l}\text { Pearson Correlation } \\
\text { Sig. (2-tailed) } \\
\mathbb{N}\end{array}$ & $\begin{array}{r}.688 " \\
.000 \\
28\end{array}$ & $\begin{array}{r}1 \\
28\end{array}$ \\
\hline
\end{tabular}

*. Correlation is significant at the 0.01 level (2-tailed)

Berdasarkan perhitungan korelasi korelasi product moment dengan menggunakan bantuan program SPSS diperoleh koefisien korelasi antara (rxy) antara kecerdasan matematis logis dengan prestasi belajar Fisika sebesar 0,000 dan signifikansi 0,000 $<0,5$ sehingga terdapat hubungan yang signifikan. Dengan demikian, Ha diterima sedangkan Ho ditolak 
sehingga dapat disimpulkan bahwa "Terdapat hubungan yang positif antara kecerdasan matematis logis dengan prestasi belajar Fisika Siswa X3 SMAN 5 Kota Ternate".

Bila dilihat dari hasil penelitian subjek penelitian ada yang memiliki tingkat kecerdasan matematis logis 'tinggi', 'sedang', dan 'rendah'. Siswa yang memiliki kecerdasan matematis logis 'tinggi' sebanyak 6 orang $(21,42 \%)$, 'sedang' sebanyak 18 orang(64,28\%) dan 'rendah' sebanyak 4 orang $(14,28 \%)$

Hasil penelitian tersebut menunjukan siswa kelas X3 SMAN 5 Ternate memiliki kecerdasan matematis logis yang paling dominan di dalam kategori sedang. Responden yang memiliki tingkat kecerdasan yang 'rendah' dapat dikatakan sedikit dengan jumlah responden 4 orang walaupun demikian siswa kecerdasan matematis logis masih sangat perlu untuk meningkatkan kecerdasannya agar dapat merasa mampu, percaya diri dan mengikuti pelajaran Fisika dan pelajaran yang membutuhkan analisis matematis dan hitungan dengan cukup baik..

Adanya kategori tinggi, rendah, dan sedang tersebut menunjukkan bahwa setiap siswa mempunyai tipe kecerdasan yang berbeda-beda. Hal ini sesuai dengan teori Armstrong (2013: 15) bahwa setiap orang memiliki kemampuan dan kapasitas dalam delapan jenis kecerdasan. Delapan kecerdasan tersebut berfungsi bersama-sama dengan cara yang unik bagi setiap orang. Beberapa orang memiliki tingkat fungsi yang sangat tinggi dalam hampir semua atau sebagian dari delapan jenis kecerdasan. Sebagian lainnya memiliki kekurangan dalam hampir semua jenis kecerdasan kecuali aspek-aspek yang paling dasar dari kecerdasan-kecerdasan tersebut. Sebagian besar berada di tingkat yang perkembangan yang tinggi dalam beberapa kecerdasan, beberapa lainnya di tingkat perkembangan yang rata-rata, dan sisanya relatif terbelakang perkembangannya. Berdasarkan teori tersebut, dapat diidentifikasi bahwa kategori rendah menunjukkan siswa dengan kecerdasan matematis yang rendah tetapi bisa tinggi di tipe kecerdasan yang lain. Kategori tinggi menunjukkan siswa dengan tipe kecerdasan logis matematisyang tinggi tetapi bisa rendah pada tipe kecerdasan yang lain. .

Kecerdasan logis matematis berhubungan dengan kemampuan dalam menggunakan angka dengan baik, melakukan penalaran dengan benar, mengolah alur pikiran yang panjang dan mencerna pola-pola logis atau numeris dengan benar. Kecerdasan yang satu ini merupakan kecerdasan yang dimiliki para ilmuwan, akuntan, dan pemrogram komputer. Menurut Prasetyo \& Andriani (2009:50), kecerdasan logika adalah kapasitas untuk menggunakan angka, berfikir logis untuk menganalisa permasalahan atau kasus dan juga melakukan perhitungan matematis. Sehingga apabila individu belajar Fisika maka diperlukan logika dalam memahami angka, menganalisa permaslahan yang berkaitan dengan perhitungan juga melakukan perhitungan dengan konsep matematis.

Sementara itu, prestasi belajar siswa Fisika juga tergolong dalam kategori sedang dengan rincian sebanyak 20 siswa $(71,4 \%)$. Sisanya terdistribusi sama rata pada kategori tinggi dan rendah dengan rincian kategori tinggi sebanyak $3(10,7 \%)$ siswa dan kategori rendah sebanyak $5(17,9 \%)$ siswa. Adanya perbedaan presentase dari setiap kategori menunjukkan adanya perbedaan prestasi belajar dari setiap siswa. Perbedaan prestasi belajar ini dipengaruhi oleh banyak faktor baik dari dalam individu maupun dari luar individu. Hasil tersebut selaras dengan pendapat Nana Syaodih (2003: 162) bahwa usaha dan keberhasilan 
belajar dipengaruhi oleh banyak faktor. Faktor-faktor tersebut dapat bersumber pada dirinya atau di luar dirinya atau lingkungannya. Salah satu faktor yang diasumsikan dalam penelitian ini yaitu kecerdasan intrapersonal yang merupakan faktor dari dalam individu yang dapat mempengaruhi prestasi belajar siswa.

Untuk mengetahui hubungan antara kecerdasan intrapersonal dengan prestasi belajar siswa, maka dilakukan analisis dengan menggunakan uji hipotesis menggunakan rumus korelasi Product Moment dengan SPSS 16. Hasil perhitungan menggunakan program SPSS 16 tersebut menunjukkan hubungan antara kecerdasan matematis logis dengan prestasi belajar Fisika sebesar 0,000 dan signifikansi 0,000 $<0,5$ sehingga terdapat hubungan yang signifikan. Hasil koefisien korelasi (rxy) menunjukkan bahwa rhitung < 0,5maka terdapat hubungan yang positif antara kedua variabel tersebut. Dengan demikian, Ha diterima sedangkan Ho ditolak sehingga dapat disimpulkan bahwa "Terdapat hubungan yang positif antara kecerdasan matematis logis dengan prestasi belajar Fisika Siswa X3 SMAN 5 Kota Ternate".

Hasil korelasi tersebut sesuai dengan pendapat yang telah diungkapkan oleh Slameto (2003: 54-59) bahwa intelegensi merupakan salah satu faktor psikologis dari dalam diri individu yang mempengaruhi individu tersebut. Intelegensi itu sendiri terbagi menjadi berbagai jenis yang disebut dengan kecerdasan majemuk. Gardner dalam Asri Budiningsih (2005: 112-116) juga menyebutkan bahwa tidak ada satupun kegiatan manusia yang hanya menggunakan satu macam kecerdasan, melainkan menggunakan seluruh kecerdasan yang selama ini dianggap ada 7 macam kecerdasan dan dalam buku tersebut ditambah dengan 2 macam kecerdasan. Adapun kontribusi dari tiap macam kecerdasan tersebut tidaklah sama untuk setiap individu. Oleh karena itu penelitian ini berusaha mengungkap seberapa besar pengaruh logis matematis sebagai salah satu dari Sembilan macam kecerdasan majemuk terhadap prestasi belajar.

\section{KESIMPULAN}

Berdasarkan hasil penelitian dan pembahasan yang dilakukan, maka dapat disimpulkan terdapat pengaruh kecerdasan matematis logis terhadap hasil belajar fisika di SMAN 5 Kota Ternate. Hal tersebut ditunjukkan dengan besarnya koefisien korelasi sebesar 0,688 dan signifikansi $0,000<0,5$ sehingga terdapat hubungan yang signifikan. Hasil koefisien korelasi (rxy) menunjukkan bahwa rhitung $<0,5$ maka terdapat hubungan yang positif antara kedua variabel tersebut.

\section{SARAN}

Berdasarkan hasil penelitian dan kesimpulan yang telah dipaparkan, maka saran yang dapat disampaikan oleh peneliti adalah sebagai berikut. Guru diharapkan dapat memperhatikan setiap jenis kecerdasan yang dimiliki siswa khususnya siswa dengan kecerdasanlogis matematis yang tinggi; Guru diharapkan mampu memfasilitasi tipe-tipe kecerdasan siswa khususnya siswa dengan kecerdasan logis matematis yang tinggi sehingga potensi siswa dapat teroptimalkan dalam rangka pencapaian prestasi belajar; Guru hendaknya mampu memotivasi dan mendorong siswa agar siswa memiliki nilai belajar fisika sesuai dengan yang diharapkan; Siswa hendaknya mampu memahami dan mengembangkan tipe kecerdasan yang dimilikinya sehingga dapat memanfaatkan potensinya secara maksimal 
untuk meningkatkan prestasi belajar khususnya mata Pelajaran fisika; Siswa diharapkan mampu dalam melakukan refleksi diri sehingga dapat mengetahui kesalahan yang dilakukan serta penyebab ketika memperoleh nilai mata Pelajaran Fisika yang kurang sesuai harapan; Orang tua hendaknya memahami bahwa setiap anak memiliki tipe kecerdasan yang berbeda; Orangtua diharapkan dapat memfasilitasi, mengarahkan, dan membimbing siswa dalam belajar sesuai dengan tipe kecerdasan yang dimilikinya khususnya siswa dengan kecerdasan intrapersonal yang tinggi; Peneliti selanjutnya diharapkan dapat mengembangkan penelitian tidak hanya terbatas pada kecerdasan intrapersonal dan matematis logis tetapi juga pada jenis kecerdasan majemuk lainnya; Peneliti selanjutnya diharapkan dapat memperluas subyek penelitian tidak hanya pada siswa kelas $\mathrm{X}^{3}$ SMAN 5 Ternate

\section{DAFTAR PUSTAKA}

Arikunto Suharsimi. 2002. Prosedur Penelitian Suatu Pendekatan Praktek, Jakarta: Rineka Cipta

Crain William. (penerjemah Yudi Santoso). 2007. Teori Perkembangan Konsep dan Aplikasi edisi ketiga. Yogyakarta. Pustaka Pelajar

Huri, Suhendri. (2011). "Pengaruh Kecerdasan Matematis-Logis dan Kemandirian Belajar Terhadap Hasil Belajar Matematika". Jurnal Formatif 1(1): 29-39 ISSN: 2088$351 \mathrm{X}$

Hurlock B, Elizabeth. (penerjemah Istiwidayanti \& Soedjarwo). Psikologi perkembangan suatu pendekatan sepanjang rentang kehidupan Edisi kelima. Jakarta: Erlangga

Lalo, Kalfaris. (2018)."Menciptakan Generasi Milenial Berkarakter dengan Pendidikan Karakter guna Menyongsong Era Globalisasi”. Volume 12. Nomor 2. Juli 2018

Lefrancois, G. R. 2000. Psychology for teaching $\left(10^{\text {th }}\right.$ ed $)$. USA: Wadsworth Thompson Learning

Nelly Anne, Clermon Perret, and Jean-Marc Barrelet. 2008. Jean Piaget and Neuchâtel The learner and the scholar. New York: Psychologi Press.

PB, Triton. 2006. SPSS 13.0 terapan riset statistic parametrik. Yogyakarta: Andi

Prasetyo, Reza dan Yeni Andriani. 2009. Multiply Your Multiple Intelligences. Yogyakarta: Andi.

Rozali, A. Yuli. (2015). "Kecerdasan Interpersonal Remaja ditinjau dari Penerapan Pola Asuh Orang Tua”. SEMINAR PSIKOLOGI \& KEMANUSIAAN (C) 2015 Psychology Forum UMM, ISBN: 978-979-796-324-8

Salim, A. (2016). “Hubungan Antara Operasi Berpikir Formal Menurut Piaget, Kemampuan Berpikir Verbal, Mekanis, Numerik, Dan Tanggapan Siswa Terhadap Pelaksanaan Problem Solving Fisika dengan Pemahaman Konsep Fluida Statis”. Prosiding semnas DEWANTARA ISSN 2528-7478

Sudarmanto, R. Gunawan. 2005. Analisis Regresi Linear Ganda Dengan SPSS. Yogyakarta: Graha ilmu

Suherman Erman, dkk. 2003. Strategi Pembelajaran Matematika Kontemporer, Universitas Indonesia

Suprapto, N \& Deta, U.A. (2012). "Pembelajaran Fisika Model Diskusi Ditinjau dari Kecerdasan Intrapersonal Siswa”. Vol 2 No 1, Juni 2012 ISSN: 2087-9946 
Suparwoto. 2007. Dasar-Dasar dan Proses Pembelajaran Fisika. Yogyakarta: Universitas Negeri Yogyakarta

Syah Muhibbin. 2004. Psikologi pendidikan dengan pendekatan baru. Bandung: Remaja Rosdakarya offset

Syamsuddin M. Abin. 2005. Psikologi pendidikan. Bandung: PT Remaja Rosdakarya

Utami, A. Dwi (2012). "Peningkatan Kecerdasan Intrapersonal Dan Kecerdasan Interpersonal Melalui Pembelajaran Project Approach".Jurnal Ilmiah VISI P2TK PAUD NI - Vol. 7, No.2, Desember 2012

Uyanto, S. Stanislaus. 2009. Pedoman analisis data dengan SPSS edisi 3. Yogyakarta: Graha ilmu 